\title{
COP9 Signalosome Complex Subunit 1
}

National Cancer Institute

\section{Source}

National Cancer Institute. COP9 Signalosome Complex Subunit 1. NCI Thesaurus. Code C26246.

COP9 signalosome complex subunit 1 (491 aa, $56 \mathrm{kDa}$ ) is encoded by the human GPS1 gene. This protein plays a role in the regulation of the ubiquitin (Ubl) conjug ation pathway and the suppression of G-protein and mitogen-activated protein kinase-mediated signal transduction. 